\title{
相関時間を考慮した非ガウス性不規則入力を受ける非線形系の応答分布*
}

\author{
土田 崇弘*1，木村 康治*2
}

\section{Response Distribution of a Nonlinear System Subjected to Non-Gaussian Random Excitation with Correlation Time}

\author{
Takahiro TSUCHIDA*1 and Koji KIMURA \\ ${ }^{* 1}$ Department of Mechanical and Environmental Informatics, Tokyo Institute of Technology \\ 2-12-1, Ookayama, Meguro-ku, Tokyo, 152-8552, Japan
}

Response distribution of a nonlinear system subjected to non-Gaussian excitation is investigated. The excitation is represented by its probability density and the auto-correlation function whose characteristic is governed by the correlation time. Both bimodal and Laplace distributions are considered as the non-Gaussianity of the excitation. In order to examine the influence of the non-Gaussianity and the length of correlation time of the excitation on the response, stationary response distributions of a Duffing system are simulated. It is shown that the response distribution is similar to the non-Gaussian distribution of the excitaiton when the correlation time is long.

Key Words : Random Vibration, Nonlinear Vibration, Forced Vibration, Duffing System, Non-Gaussian Excitation, Correlation Time, Response Distribution

1. 緒言

機械や構造物は，地震動や風荷重などの不規則な励振を受ける .これらの系の動的挙動を明らかにすることは， 安全性の維持, 信頼性の向上のために重要な課題である. 過去の研究では, ガウス性不規則入力を扱ったものが 多く, 光の入力を受ける系の応答解析については, 多樣な研究成果が報告されている ${ }^{(1)(2)}$.

しかし, 実際の不規則励振の中には, 兴の確率密度関数が非ガウス性の入力も存在する.例えば, ガウス性入 力を受ける非線形系の応答は, 非ガウス性となることが知られている(3)(4)(5)が, この応答が次の系に入力として作 用する場合，この系は非ガウス性入力を受けることになる．また，異なる励振源から発生する入力を系が同時に 受けるとき，系にはたらく入力は非ガウス性となる ${ }^{(6)(7)}$. 非ガウス性入力を扱った応答解析は, 次第に増えてきて いる ${ }^{(8)(9)(10)}$ が, 弚の応答特性については, 未だ十分に明らかとなっていない .

本研究では, 非ガウス性不規則入力を受ける系の応答分布について調べることを目的として，系の応答計算を 行う. 非ガウス性入力は, 確率密度関数と, 相関時間をパラメータにもつ指数減衰相関関数によって表す.このと き, 非ガウス分布として, 分布の特徵に相違があり, 加えてガウス分布とも形状が異なるバイモーダル分布とラ プラス分布を扱う .また , 相関時間については, 入力の相関特性が大きく異なる場合を考慮できるように, 短い時 間から長い時間まで広い範囲を対象としている. Kontrovich と Lyandres の手法 ${ }^{(11)}$ を用いて , 入力の標本関数を生 成し，これらの入力を受ける線形系と Duffing 系の定常応答分布を数値計算によって求め，入力の分布形状と相関 時間の違いが応答に与える影響を調べる.

* 原稿受付 2011 年 7 月 28 日

*1 学生員, 東京工業大学大学院情報理工学研究科情報環境学専攻 （干152-8550 東京都目黒区大岡山 2-12-1）

*2 正員, フェロー，東京工業大学大学院情報理工学研究科情報環境学専攻

E-mail: kkimura@mei.titech.ac.jp 


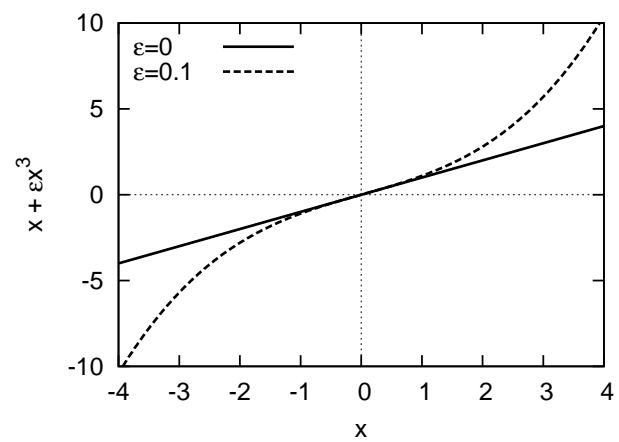

Fig. 1 Restoring force

\section{2. 運 動 方 程 式}

次式の運動方程式によって記述される 1 自由度 Duffing 系を考える．

$$
\ddot{x}+2 \zeta \dot{x}+x+\varepsilon x^{3}=u(t)
$$

ここで, $\zeta$ は減衰比， $\varepsilon$ は非線形パラメータで, $\varepsilon=0$ の場合は,線形系となる . 図 1 に $, \varepsilon=0,0.1$ の場合のばね 特性を示す. また,$t$ は不減衰固有振動数で無次元化した時間であり，ドットは $t$ での微分を表す.$u(t)$ は相関特性 を考慮した非ガウス性不規則入力で, 確率密度関数と自己相関関数によって表される $u(t)$ の平均值は 0 とする.

\section{3. 非ガウス性不規則入力}

\section{$3 \cdot 1$ 入力の自己相関関数と確率密度関数}

非ガウス性不規則入力 $u(t)$ の自己相関関数 $R_{u}(\tau)$ として , 次式に示すような指数減衰関数を考える .

$$
R_{u}(\tau)=\mathrm{E}\left[u^{2}\right] \exp \left(-\frac{|\tau|}{\tau_{u c o r r}}\right)
$$

ここで, $\tau_{u c o r r}$ は入力の相関時間である . また , 入力のパワースペクトル $S_{u}(\omega)$ は , Wiener-Khintchine の定理より， 次式のように表される .

$$
S_{u}(\omega)=\frac{1}{2 \pi} \int_{-\infty}^{\infty} R_{u}(\tau) e^{-i \omega \tau} d \tau=\frac{\mathrm{E}\left[u^{2}\right] \tau_{u c o r r}}{\pi\left(1+\omega^{2} \tau_{u c o r r}^{2}\right)}
$$

図 2,3に, $\mathrm{E}\left[u^{2}\right]=1.0, \tau_{u c o r r}=1,10,20,50,100$ の場合の $R_{u}(\tau)$ と $S_{u}(\omega)$ を示す.相関時間 $\tau_{u c o r r}$ を変化させ ることで , 樣々な帯域幅を有する入力を表現できる . 相関時間の短い場合は，広帯域な入力となる . また , 相関 時間の長い場合は，低周波数成分が卓越した入力となる .

次に, 非ガウス性入力 $u(t)$ の確率密度関数 $p_{u}(u)$ につて考える . 入力の分布形状の違いが応答に与える影響 を調べるため, 確率密度関数として, 従来の研究で多く用いられているガウス分布とは形状が大きく異なり, 加 えて互いの分布の特徵にも大きな違いがある次の 2 つを扱う .

バイモーダル分布

$$
p_{u}(u)=C \exp \left(a u^{2}+b u^{4}\right) \quad(a>0, b<0)
$$

ラプラス分布

$$
p_{u}(u)=\frac{\beta}{2} \exp (-\beta|u|) \quad(\beta>0)
$$

ここで, $a, b, \beta$ は分布形状を決定するパラメータ, $C$ は正規化定数である. 分布形状が大きく異なる 2 通りの入 力を対象とすることによって , 非ガウス性入力を受ける系の応答特性に関する知見が得られることが期待される . 


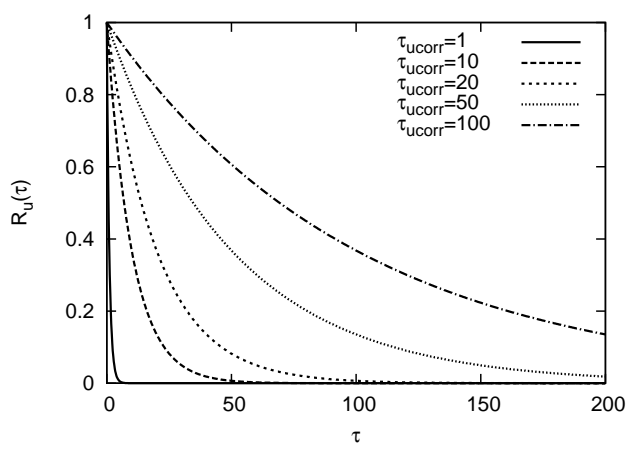

Fig. 2 Auto-correlation function

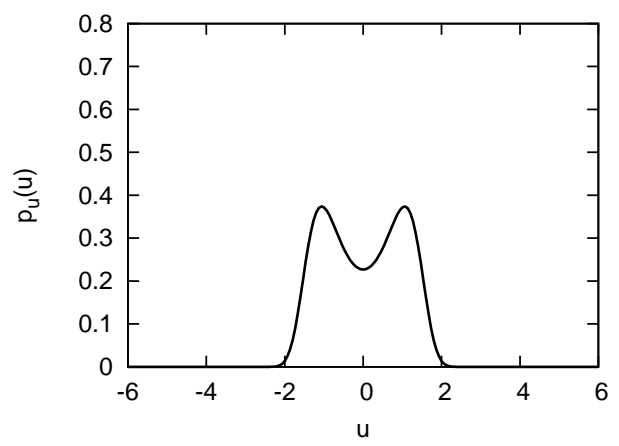

Fig. 4 Bimodal distribution

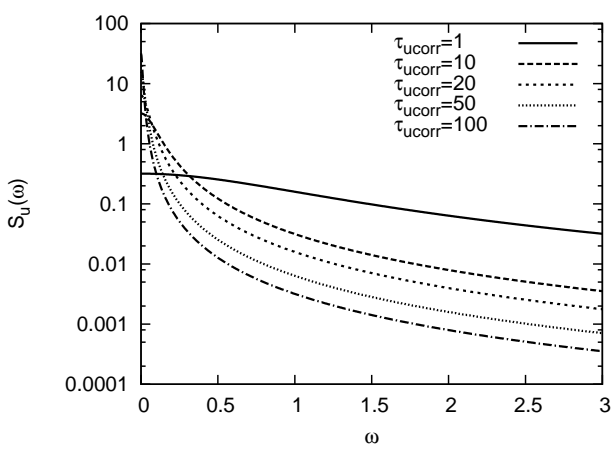

Fig. 3 Power spectrum

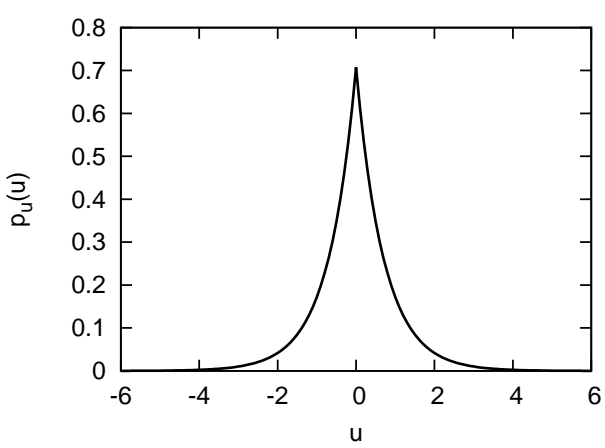

Fig. 5 Laplace distribution

本研究では, 入力の分布 $p_{u}(u)$ と相関時間 $\tau_{u c o r r}$ の違いが応答に与える影響について調べることを目的とするため， どちらの分布に対しても，同じ自己相関関数をもつように , パラメータの值を次のように設定する .

$$
a=0.8935, b=-0.3991, \beta=\sqrt{2}
$$

このとき，両分布の二乗平均值は, $\mathrm{E}\left[u^{2}\right]=1.0$ となる . 図 4,5 に , このときのバイモーダル分布とラプラス分布 を示す.また，これらの非ガウス分布との比較のために，平均 0, 分散 1 のガウス分布も扱う .

\section{$3 \cdot 2$ 入力の生成方法}

3.1 節で示した確率密度関数と自己相関関数を有する入力 $u(t)$ を生成するために , Kontrovich と Lyandresによ り提案された手法 ${ }^{(11)}$ を用いる. 本節では, 光の手法の概要を説明する.

式 (2) で表される自己相関関数をもつ入力 $u(t)$ は, 次式で示すような, 一階の微分方程式で表すことができる .

$$
\frac{d u(t)}{d t}=h(u)+g(u) \xi(t)
$$

ここで, $h(u), g(u)$ は確定的な関数であり, $\xi(t)$ は強度 $1 / 2 \pi$ のガウス性ホワイトノイズである.

入力 $u(t)$ の確率密度関数 $p_{u}(u, t)$ は, 次式に示す, Fokker-Planck 方程式によって記述される .

$$
\begin{aligned}
& \frac{\partial p_{u}(u, t)}{\partial t}=-\frac{\partial}{\partial u}\left(K_{1}(u) p_{u}(u, t)\right)+\frac{1}{2} \frac{\partial^{2}}{\partial u^{2}}\left(K_{2}(u) p_{u}(u, t)\right) \\
& K_{1}(u)=h(u)+\frac{1}{4} \frac{d}{d u} g^{2}(u) \\
& K_{2}(u)=g^{2}(u)
\end{aligned}
$$

式 (9) の右辺第 2 項は, 式 (7) を伊藤型の確率微分方程式で表す際に生じる補正項である ${ }^{(12)}$.このとき, 式 (8)の 定常解 $p_{u}(u)$ は次式のように与えられる.

$$
p_{u}(u)=\frac{C}{g^{2}(u)} \exp \left\{2 \int_{a}^{u} \frac{h(s)}{g^{2}(s)} d s\right\}
$$


式(11)を $h(u)$ につて解くと，次のようになる .

$$
h(u)=\frac{1}{2}\left\{g^{2}(u) \frac{d}{d u} \ln p_{u}(u)+2 g(u) \frac{d}{d u} g(u)\right\}
$$

ここで, $g(u)=\sqrt{K}$ ( $K$ は定数) とすると, 式 (7)，(12)より，入力 $u(t)$ の生成式が導かれる.

$$
\frac{d u}{d t}=\frac{K}{2} \frac{d}{d u} \ln p_{u}(u)+\sqrt{K} \xi(t)
$$

また，Kについては，次の関係式を計算することで, 光の值を求めることができる .

$$
\tau_{u c o r r}=\left|\left[\frac{E\left[u^{4}\right]}{3 ! E\left[u^{2}\right]} \frac{d^{3} h(0)}{d u^{3}}+\frac{d h(0)}{d u}\right]^{-1}\right|
$$

\section{4. 計算方法とパラメータ}

\section{$4 \cdot 1$ 計算方法}

式 (13) を数値計算で解き, 入力の標本関数を生成する. 光して，これを用いて，式 (1) で記述される系の応答 計算を行い，定常応答分布を求める．このとき，いずれの計算にも Runge-Kutta 法を用いる．また，式 (13) の計 算時に必要なホワイトノイズ $\xi(t)$ の生成には, 文献 (13) の方法を用いる.

\section{$4 \cdot 2$ 計算パラメータ}

計算に用いる，入力の相関時間 $\tau_{u c o r r}$ と系の減衰比 $\zeta$, 非線形パラメータ $\varepsilon$ の值を以下に示す .

$$
\begin{aligned}
& \tau_{\text {ucorr }}=1,20,100 \\
& \zeta=0.05 \\
& \varepsilon=0,0.1
\end{aligned}
$$

入力の相関時間 $\tau_{u c o r r}$ については, 入力の帯域幅を表す $1 / \tau_{u c o r r}$ が, 線形系の周波数応答の帯域幅を表す減衰比

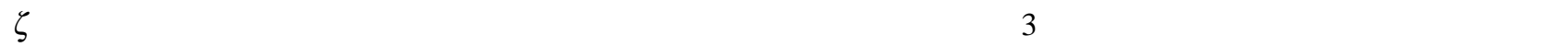
率密度関数 $p_{u}(u)$ として，3.1 節で述べたバイモーダル分布 (式 (4)) とラプラス分布 (式 (5)) を扱う. 分布形状を決 定するパラメータは, 式(6)のように設定する .

系は，減衰比 $\zeta$ の值を固定し， $\varepsilon=0$ の線形系の場合と， $\varepsilon=0.1$ の Duffing 系の場合を考える．

\section{5. 計 算 結 果}

相関時間 $\tau_{u c o r r}$ の異なるバイモーダル分布入力を受ける，線形系 $(\varepsilon=0)$ と Duffing 系 $(\varepsilon=0.1)$ の定常応答分布 を図 6 に示す . 同樣に , ラプラス分布入力を受ける系の応答分布を図 7 に示す . また , これらの非ガウス性入力 に対する応答との比較のために, ガウス性入力を受ける系の応答分布を図 8 に示す. 計算結果をもとに , 入力の 分布形状と相関時間の違い，および系の非線形性が応答分布に与える影響を考察する .

\section{$5 \cdot 1$ 相関時間が短い場合}

図 6,7,8の $\tau_{u c o r r}=1, \varepsilon=0$ (線形系) の場合の応答分布を比較すると，入力の分布形状が大きく異なるにも関 わらず，同一のガウス分布となっている.また， $\tau_{u c o r r}=1, \varepsilon=0.1$ (Duffing 系) の応答分布についても同一形状の 非ガウス分布となっている．したがって，相関時間が短い場合の応答分布には，系の非線形性の影響は現れるが， 入力分布の特徵は反映されないということが分かる.このような傾向か現れるのは, $\tau_{u c o r r}=1$ の場合, 図 $2,3 に$ 示すように , 入力がホワイトノイズに近いものとなるためであると考えられる .

Duffing 系が強度 $S_{0}$ のホワイトノイズを受けるとき, 応答分布の厳密解は次のように表される ${ }^{(14)}$.

$$
p_{x}(x)=C \exp \left[-\frac{2 \zeta}{\pi S_{0}}\left(\frac{x^{2}}{2}+\varepsilon \frac{x^{4}}{4}\right)\right]
$$

ここで, $\varepsilon=0$ の場合は, 線形系の応答分布に対応する.したがって , 相関時間が短い場合の応答分布は, 近似的に 式(15)で表せると考えられる.実際に，図 6,7,8 の計算結果は, 式(15)に $S_{0} \approx 0.5 S_{u}(0)(\varepsilon=0), S_{0} \approx 0.45 S_{u}(0)$ 
$(\varepsilon=0.1)$ を代入した関数形状にほぼ一致することを確認した .

\section{$5 \cdot 2$ 相関時間が長い場合}

図 6,7より，線形系と Duffing 系では，応答分布に系の違いによる差異が見られるものの，入力が非ガウス性 の場合，系か線形であるか非線形であるかに関わらず， $\tau_{\text {ucorr }}$ の值が大きくなるにつれて，応答分布は入力の非ガ ウス分布 (図 4，5) に近い形状に変化していくことが分かる. 弚の結果， $\tau_{u c o r r}=100$ のとき，入力分布の違いに よって，図 6 と図 7では, 全く異なる形状の応答分布か現れている.

次に, 入力波形と応答波形の比較を行う．応答分布と同樣の傾向が，図 9 に示す， $\tau_{u c o r r}=1,100$ のバイモーダ ル分布入力と，光の入力を受ける線形系の応答の時系列からも確認できる $\tau_{u c o r r}=1$ の入力に対する応答には, 入 力の特徵か現れていないのに対し， $\tau_{u c o r r}=100$ の場合では，応答波形が入力波形に非常に近いものとなっている.

図 8 の $\tau_{\text {ucorr }}=100$ のガウス性入力を受ける Duffing 系の応答は非ガウス分布である . しかし , この非ガウス性 は, 系の非線形性によって生じたものであり，上で述べた非ガウス性入力の場合のように , 入力の分布形状を反映 して現れた性質ではない .
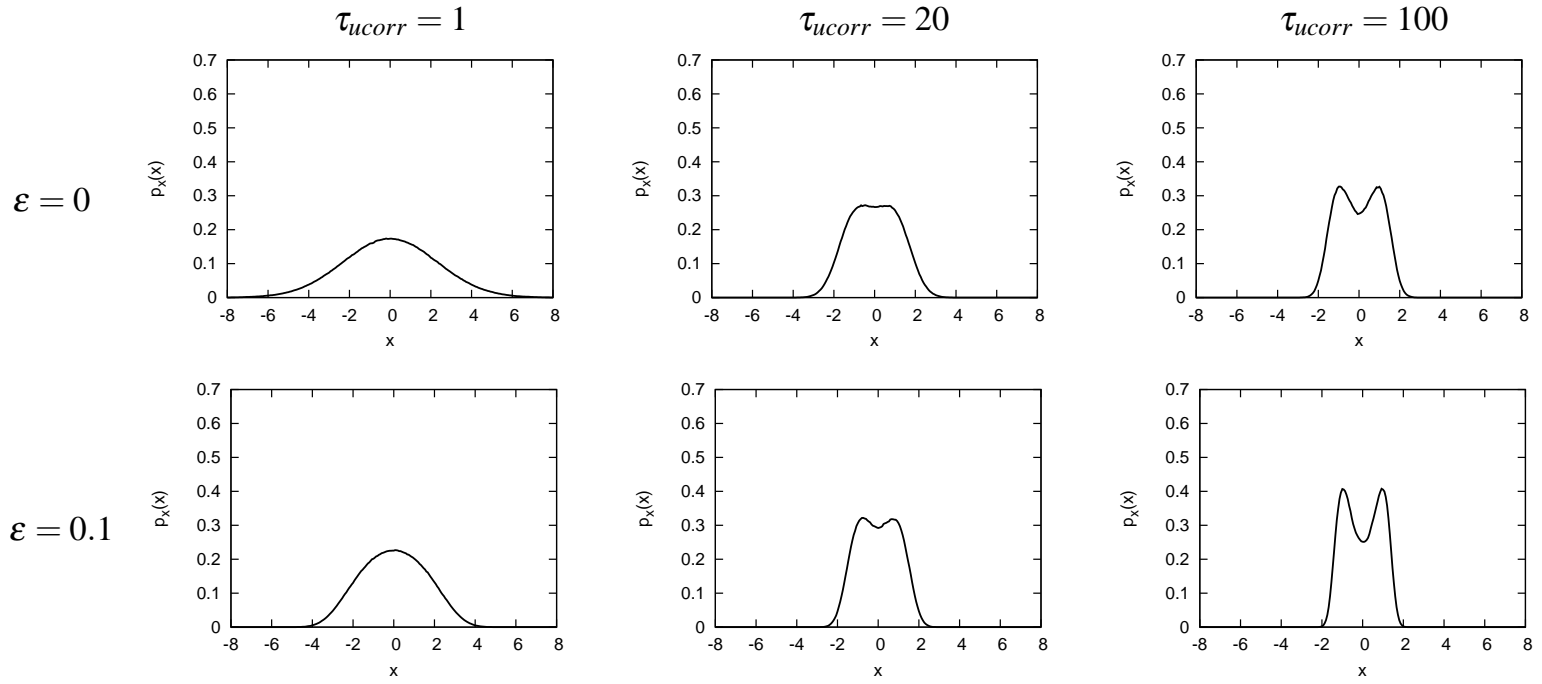

Fig. 6 Response distribtution of linear $(\varepsilon=0)$ and Duffing $(\varepsilon=0.1)$ systems subjected to bimodaldistributed excitation with different correlation time
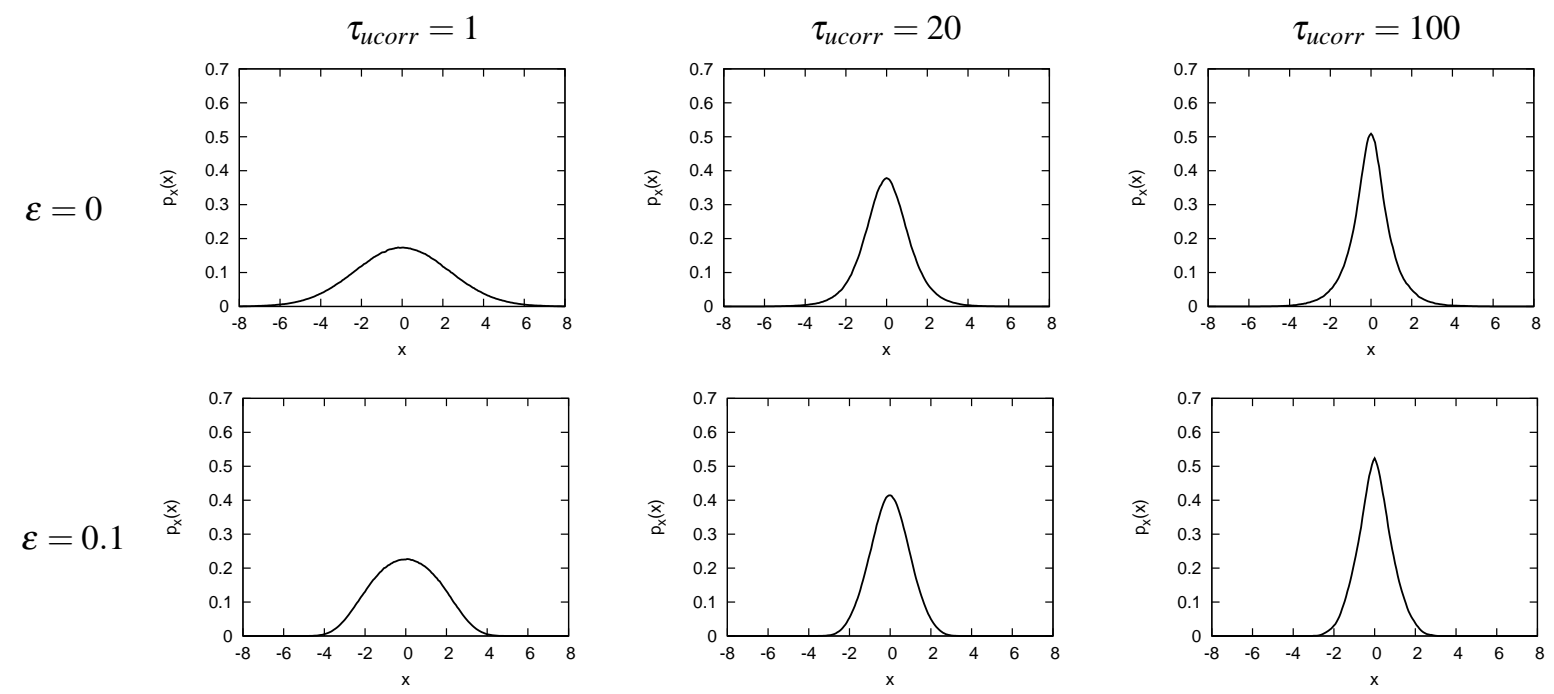

Fig. 7 Response distribtution of linear $(\varepsilon=0)$ and Duffing $(\varepsilon=0.1)$ systems subjected to Laplacedistributed excitation with different correlation time 
$\tau_{\text {ucorr }}=1$
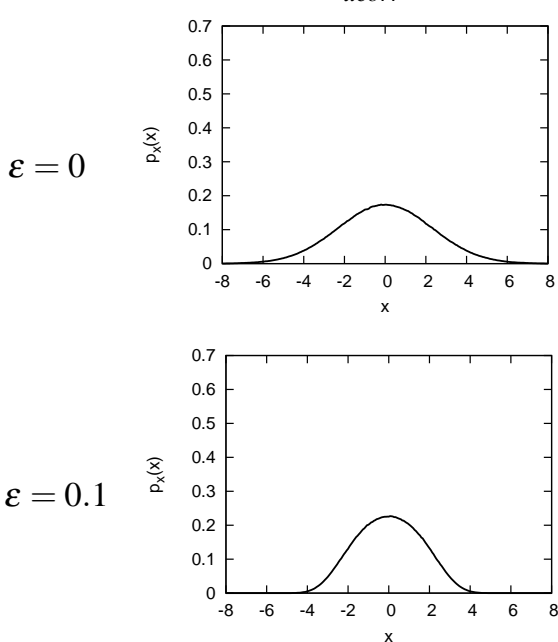

$\tau_{\text {ucorr }}=20$
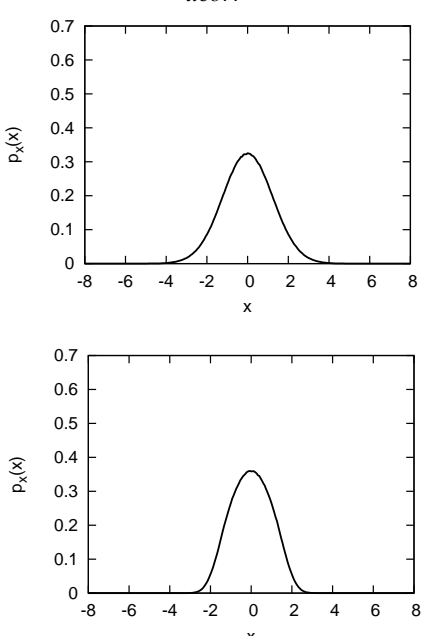

$\tau_{\text {ucorr }}=100$
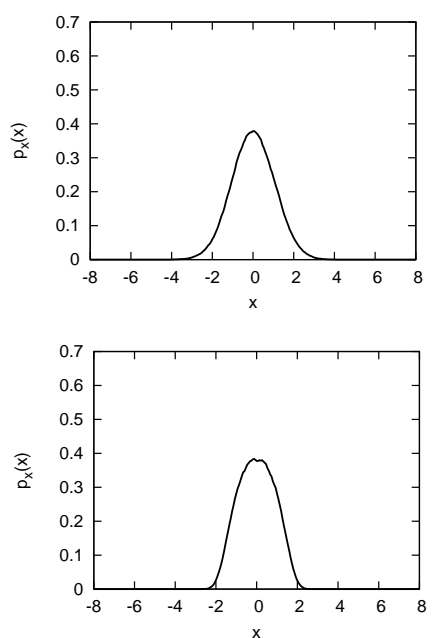

Fig. 8 Response distribtution of linear $(\varepsilon=0)$ and Duffing $(\varepsilon=0.1)$ systems subjected to Gaussian excitation with different correlation time

$\tau_{\text {ucorr }}=1$
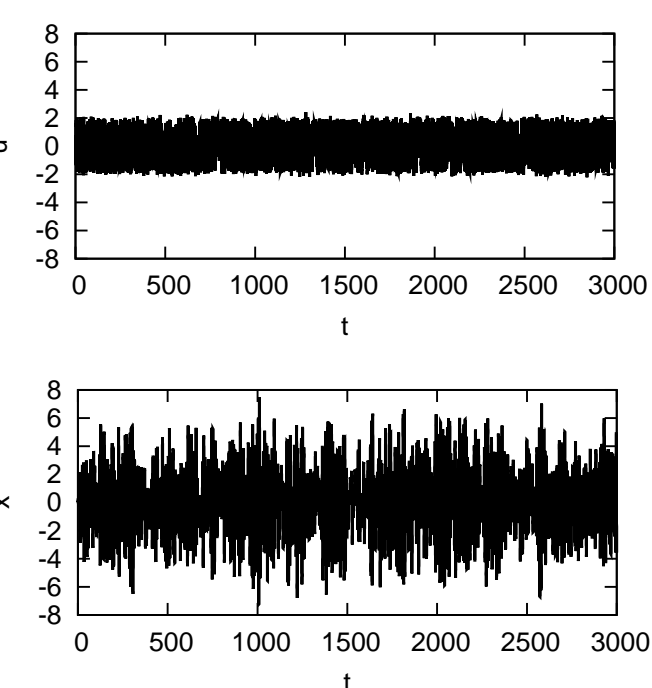

$\tau_{\text {ucorr }}=100$
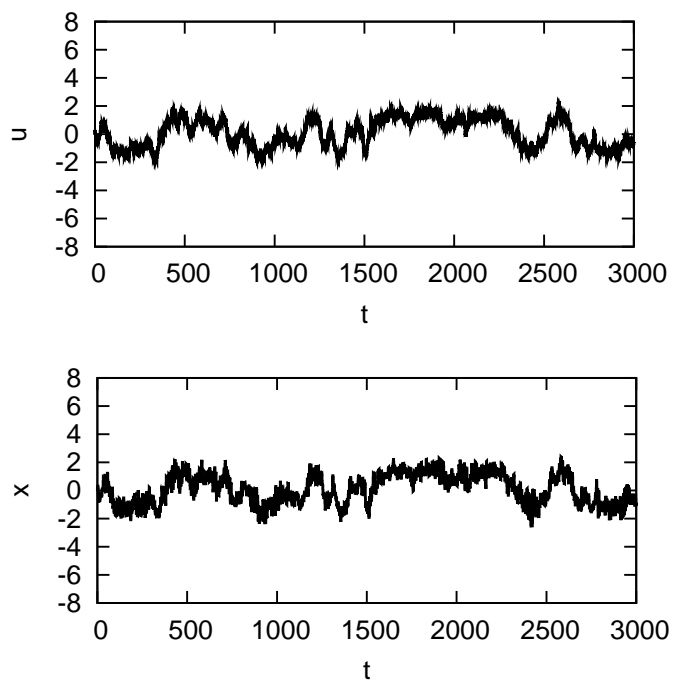

Fig. 9 Time series of bimodal-distributed excitation and response of linear system

以上の計算例が示すように, 応答分布が非ガウス性となる理由として, 入力の非ガウス性と系の非線形性が挙 げられるが, ガウス性入力の場合には , 入力が非ガウス性を有しないため, 系の非線形性のみに依存した非ガウス 分布となる . 一方 , 非ガウス性入力の場合 , 入力の非ガウス性と系の非線形性の両方を反映した応答分布となる が, 弚の分布形状には, 系の非線形性に比べて, 入力の分布形状の特徵が非常に強く現れることが, 分布形状の 大きく異なる 2 種類の非ガウス分布入力に対する応答分布から明らかになった . ただし , 非線形パラメータ $\varepsilon$ が 今回用いた值に比べてとても大きい場合や，系が異なる非線形性を有する場合には，応答分布に系の特性か顕著 に現れる場合もあると考えられる .

図 6,7，8 において，線形系と Duffing 系の応答分布の幅に着目すると，入力の分布形状と相関時間の長さによ らず, Duffing 系の応答分布は, 弚の硬性ばね特性 (図 1)により, 線形系の場合に比べて狭まることが分かる.

\section{3 入力の相関時間と応答分布の関係についての考察}

5.1 節と 5.2 節で得られた応答分布と時系列に関する知見を，入力と応答のパワースペクトルから考察する． まず, 線形系の場合を考える . 応答パワースペクトル $S_{x}(\omega)$ は , 入力パワースペクトル $S_{u}(\omega)$ と周波数応答関 

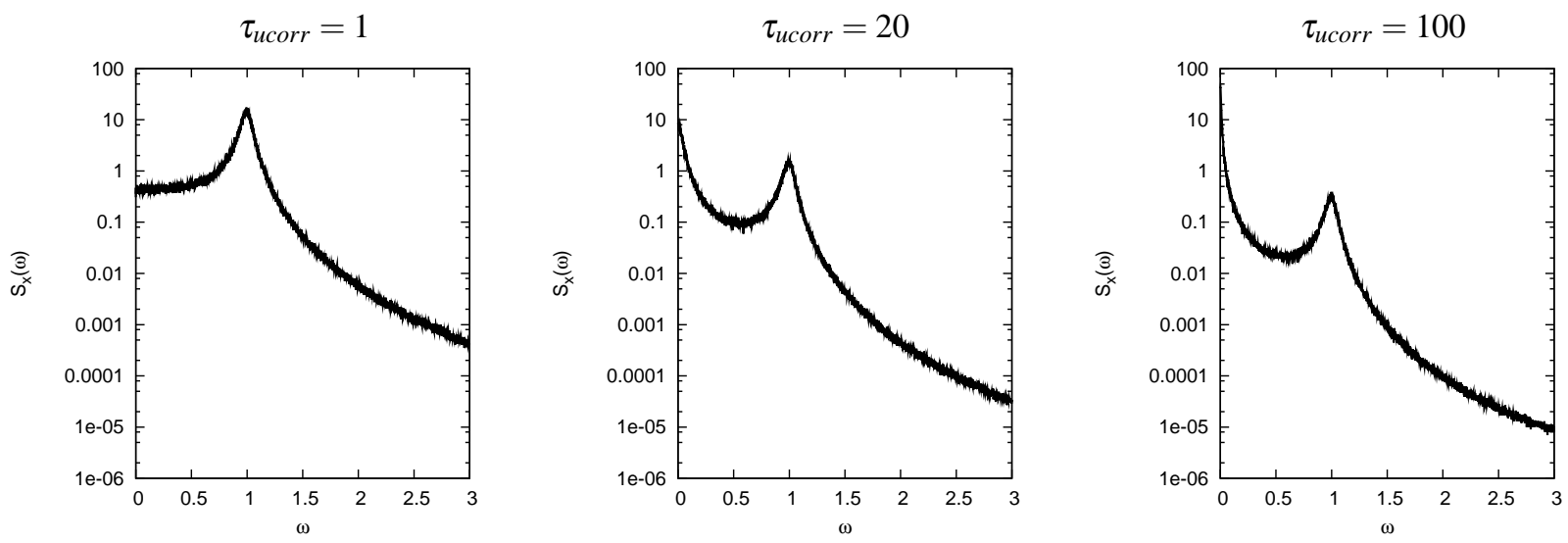

Fig. 10 Response power spectrum of linear system
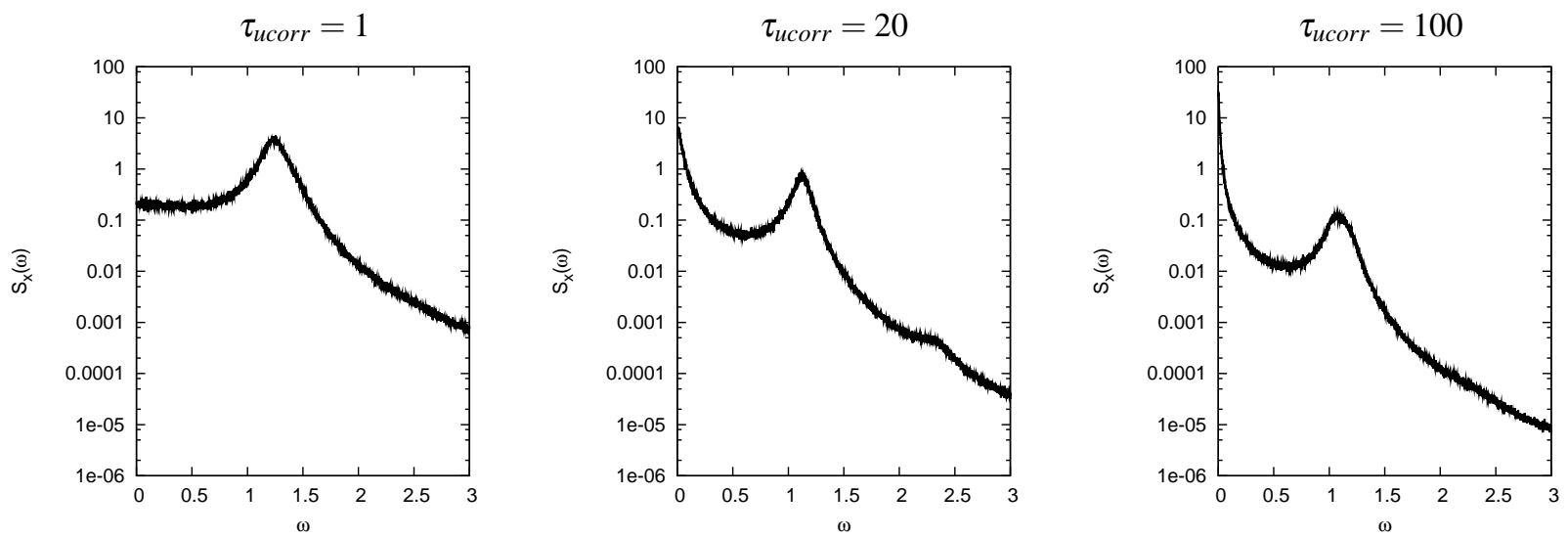

Fig. 11 Response power spectrum of Duffing system subjected to bimodal-distributed excitation

数 $|H(\omega)|^{2}$ の積で与えられる . また ，本研究では，いずれの分布に対しても，同じ $S_{u}(\omega)$ をもつように設定した 弚のため, $S_{x}(\omega)$ は入力の分布形状によらない. 図 10 に，応答の標本関数から得られた， $\tau_{u c o r r}=1,20,100$ の

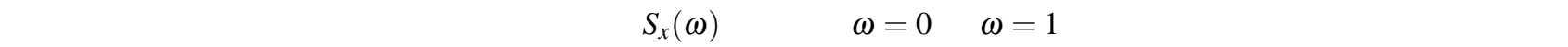
る.これらは入力と系の性質を受けて生じたものであるため, 2つのピークの大小関係から , 応答が , 入力と系の どちらの影響を強く受けているかを判断できる．

$\tau_{u c o r r}=1$ の場合， $S_{x}(\omega)$ には， $\omega=1$ のピークのみか現れている.このことから， $\tau_{u c o r r}$ が小さい場合，応答は 入力よりも系の影響を強く受け, 光のため, 応答分布や時系列に入力とは異なった特徵か現れると考えられる.

$\tau_{\text {ucorr }}$ が大きくなるにつれて,$S_{x}(\omega)$ の $\omega=0$ のピークは大きくなり， $\omega=1$ のピークは小さくなる . したがっ て, $\tau_{\text {ucorr }}$ が大きいほど, 応答に与える入力の影響が強まり，系の影響は弱まるため，応答に入力の非ガウス性が 強く現れると考えられる .

次に, Duffing 系の場合について考える . 図 11 に， $\tau_{u c o r r}=1,20,100$ のバイモーダル分布入力を受ける Duffing 系の応答パワースペクトルを示す. 線形系の場合 (図 10)に $\omega=1$ に位置した , 系の影響により生じるピークが， $\omega>1$ の位置にずれて現れている.これは, 硬性ばねをもつDuffing 系の共振振動数が, 線形系の固有振動数より も大きくなるためである . 非線形系の応答パワースペクトルについては , 入力のパワースペクトル $S_{u}(\omega)$ との関 係を線形系のように式で記述することはできないものの， $S_{u}(\omega)$ の特性が大きく関わっていると考えられる．した がって, 共振振動数の位置に現れるピークと, 入力の性質により生じる $\omega=0$ のピークの大小関係を比較すること により，線形系の場合と同樣の基準で，応答が入力と系のどちらの影響を強く受けているかを判断できる． $S_{u}(\omega)$ は, 図 3 のように, $\tau_{\text {ucorr }}$ が大きくなるにつれて， $\omega=0$ のピークは大きくなり，乥れ以外の周波数成分は小さく

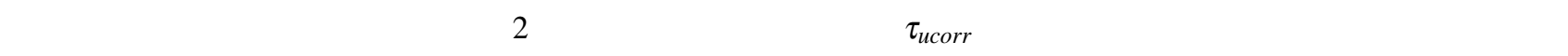
化を示している．したがって， $\tau_{u c o r r}$ が大きくなるほど，応答は入力の影響を強く受けるようになり，弚の結果， 応答分布が入力分布に近い形状になると考えられる． 


\section{6. 結 論}

確率密度関数と相関時間によって表される非ガウス性不規則入力を受ける系の応答計算を行った . 入力の確率 密度関数として, 分布の形状に大きな違いがあるバイモーダル分布とラプラス分布を扱った . また，相関時間の 長さについては , 入力の帯域幅と線形系の周波数応答の帯域幅の比が大きく異なる場合を考慮するために，短い ものから長いものまで対象とした .これらの分布と相関時間を有する入力を生成し，光の入力を受ける線形系と Duffing 系の定常応答分布を求めた . 入力の分布形状と相関時間の違いが応答分布に与える影響について考察し， 以下の知見が得られた .

・ 入力の相関時間が短い場合，応答分布は，入力の分布形状の違いによらず, 同一の分布となることを示した . また , 谷の分布が, ホワイトノイズを受ける系の厳密解に近い形状であることを確かめた .

- 相関時間が長い非ガウス性入力を受ける線形系および Duffing 系の応答分布は, 入力に近い形状の非ガウス分 布となり, 入力分布の違いによって，応答の分布形状に大きな違いか現れることを，分布形状が大きく異な る 2 種類の入力に対する応答分布から明らかにした .

- 入力の相関時間と応答分布の間に見られる関係を，応答のパワースペクトルに現れる2つのピークの大小関 係から考察した . そして, 入力分布の特性によらず, 相関時間が長いほど, 応答に与える入力の影響が強ま ることを示した

\section{文献}

(1) Crandall, S.H., Zhu, W.Q., "Random vibration - A survey of recent developments", Journal of Applied Mechanics, Vol. 50, No. 4B (1983), pp. 953-962.

(2) Zhu, W.Q., Cai, G.Q., "Nonlinear stochastic dynamics: A survey of recent developments", Acta Mechanica Sinica, Vol. 18, No. 6 (2002), pp. 551-566.

(3) Kimura, K., Yasumuro, H., Sakata, M., "Non-Gaussian equivalent linearization for non-stationary random vibration of hysteretic system”, Probabilistic Engineering Mechanics, Vol. 9, No. 1-2 (1994), pp. 15-22.

(4) 田村晋司, 高橋拓也, 木村康治, “狭帯域不規則励振を受ける Duffing 系のジャンプ現象を伴う応答の確率密度の解析”, 日本 機械学会論文集 C 編, Vol. 75, No. 754 (2009), pp. 1550-1559.

(5) Cai, G.Q., Lin, Y.K., "Exact and approximate solutions for randomly excited MDOF non-linear systems", International Journal of Non-Linear Mechanics, Vol. 31, No. 5 (1996), pp. 647-655.

(6) Grigoriu, M., "A Partial Differential Equation for the Characteristic Function of the Response of Non-Linear Systems to Additive Poisson White Noise", Journal of Sound and vibration, Vol. 198, No. 2 (1996), pp.193-202.

(7) 須田紘司, 木村康治, “白色励振と不規則パルス励振を同時に受ける非線形系の応答分布”, 日本機械学会東海支部第 60 期 総会講演会講演論文集, No. 113-1 (2011), 808.

(8) Cai, G.Q., Lin, Y.K., "Response Distribution of Non-Linear Systems Excited by Non-Gaussian Impulsive Noise", International Journal of Non-Linear Mechanics, Vol. 27, No. 6 (1992), pp. 955-961.

(9) Sobiechowski, C., Socha, L., "Statistical Linearization of the Duffing Oscillator under Non-Gaussian External Excitation", Journal of Sound and vibration, Vol. 231, No. 1 (2000), pp. 19-35.

(10) Zeng, Y., Zhu, W.Q., "Stochastic averaging of n-dimensional non-linear dynamical systems subject to non-Gaussian wide-band random excitations", International Journal of Non-Linear Mechanics, Vol. 45, No. 5 (2010), pp. 572-586.

(11) Kontrovich, V.Y., Lyandres, V.Z., "Stochastic Differential Equations: An Approach to the Generation of Continuous NonGaussian Processes”, IEEE Transactions on Signal Processing, Vol. 43, NO.10 (1995), pp. 2372-2385.

(12) T.T.Soong, Random Differential Equations in Science and Engineering, (1970), Academic Press.

(13) 日本機械学会編, 機械工学便覧基礎編 $\alpha 2$ 機械力学, (2004), pp. 98-99 丸善. 
(14) Caughey, T.K., "Derivation and Application the Fokker-Planck Equation to Discrete Nonlinear Dynamics Systems Subjected to White Random Excitation”, The Journal of Acoustical Society of America, Vol. 35, No. 11 (1963), pp. 1687-1692. 